\title{
Developing Market Specific Supply Chain Strategies
}

\section{Martin Christopher, Cranfield School of Management, Cranfield University, Bedford, MK43 0AL \\ Denis R. Towill, Cardiff Business School, Cardiff University, Colum Drive, Cardiff, CF10 3EU}

This paper examines the issues underlying the appropriate matching of pipelines to marketplace needs under conditions of demand volatility and price pressure. It describes a scenario where the philosophy of "one size fits all" does not apply to pipeline design, implementation, and control. The paper reports on research conducted by the authors and others on how appropriate global supply chain strategies can be developed contingent upon market characteristics and which seek simultaneously to achieve higher levels of customer responsiveness at less total cost to the supply chain as a whole. The selection of the right strategy within a supply chain lends itself to a taxonomic approach. We find that three dimensions (leading to eight possible configurations) are adequate for this purpose. These key dimensions are product characteristics, demand characteristics and replenishment lead-time.

Over the last decade or so, there has emerged a view that recognises that the route to competitive advantage lies through the supply chain. Indeed, it has been suggested that "supply chains compete, not companies" (1). The idea being that the unique set of relations that typify the web of inter-connections between organisations in a network enable the achievement of competitive advantage through lower costs and/or greater differentiation.

Because of the complexity of todays supply chains, due in part to out-sourcing and globalisation, the way in which these relationships are structured and managed can make the difference between profit and loss.

As McCullen and Towill (2) have shown, globalisation of supply chains compounds the logistical problem along three dimensions. These are replenishment level; time; and distance. Hence a marketplace ripple can be amplified and distorted as it passes 
from, say, the UK to Indonesia. Furthermore, there may well be a significant delay before any response occurs at (say) the raw material supplier. Additionally, customer choice and the nature of the product means that in pipeline terms "one size does not fit all" $(3,4)$. Hence matching the pipeline to the product is a key issue in the engineering of global supply chains.

Many marketplaces are now highly volatile and demand is difficult to predict. The acceleration of technological and fashion changes has additionally resulted in extremely short product life cycles. In this new environment non-availability means that in the event of non-supply the particular sales opportunity is lost forever (5). Consequently the focus in supply chain management must shift from the idea of cost as the order winner to responsiveness as the market winner. The implication is that the emphasis in supply chain management in the future must be on agility.

Agility implies the ability of the supply chain to react quickly to changes in market demand - be they changes in volume, variety or mix. The characteristics of the agile supply chain have been described elsewhere (6), but it is useful to contrast agility with the philosophy of lean operations. Lean thinking is most often associated with the car assembly industry and Japan in particular. Agility \& leanness are not opposing philosophies, rather they work best in certain contexts as Table 1 suggests. 


\begin{tabular}{|l|l|l|}
\hline $\begin{array}{l}\text { DISTINGUISHING } \\
\text { ATTRIBUTES }\end{array}$ & LEAN SUPPLY & AGILE SUPPLY \\
\hline Typical Products & Commodities & Fashion Goods \\
\hline Marketplace Demand & Predictable & Volatile \\
\hline Product Variety & Low & High \\
\hline Product Life Cycle & Long & Short \\
\hline Customer Drivers & Cost & Availability \\
\hline Profit Margin & Low & High \\
\hline Dominant Costs & Physical Costs & Marketability \\
\hline Stockout Penalties & Long Term Contractual & Immediate and Volatile \\
\hline Purchasing Policy & Buy Goods & Assign Capacity \\
\hline Information Enrichment & Highly Desirable & Obligatory \\
\hline Forecasting mechanism & Algorithmic & Consultative \\
\hline
\end{tabular}

Table 1

Comparison of Lean Supply with Agile Supply : the Distinguishing Features (Source: Mason-Jones, Naylor and Towill (7))

\section{Quick Response Movement}

The Quick Response (QR) movement originating in the USA textile and apparel industries can be seen as an excellent model for time-compressing supply chains because of its emphasis on co-operative efforts among all members of the chain from raw materials right through to the end customer (8). The catalyst for the QR movement in apparel was competition from offshore manufacturers. For example in 1988, 50 percent of the apparel and textiles purchased in the United States were imported from the Orient. The outcome of the debate over how best to respond to this situation within the industry was the formation of the QR movement.

The Council also recognised that "closer to the customer" means closer in time more than closer in distance. In Hill's (9) terminology the "market winner" in apparel is fashion, and in the fashion business timing is everything since today's style is tomorrow's markdown (10). Hence successful firms are those that can ride the latest wave of fashion. For apparel manufacturers, response time is the key. So it is 
essential to judge quickly what is selling and move it through the pipeline and onto the racks before competitors (11).

Quick response provides a remedy to this problem by compressing the total pipeline, thus eliminating some of those efficiency losses by moving manufacturing closer to the consumer's buying decision. Long pipelines also means that forecast horizons are extended with the inevitable impact on forecast errors. As a rule of thumb the forecast errors are as follows:

- Start of Season $\pm 10 \%$

- Minus 16 weeks $\pm 20 \%$

- Minus 26 weeks $\pm 40 \%$

QR has been defined at length by Lowson et al (12) as:

"A state of responsiveness and flexibility in which an organisation seeks to provide a highly diverse range of products and services to a customer/consumer in the exact quantity, variety and quality, and at the right time, place and price as dictated by realtime customer/consumer demand. QR provides the ability to make demand information driven decisions at the last possible moment in time ensuring that diversity of offering is maximised and lead-times, expenditure, cost and inventory minimised. QR places an emphasis upon flexibility and product velocity in order to meet the changing requirements of a highly competitive, volatile and dynamic marketplace. QR encompasses a strategy, structure, culture and set of operational procedures aimed at integrating enterprises in a mutual network through rapid information transfer and profitable exchange of activity."

The significant conceptual breakthrough made in the QR movement was identifying and exploiting the fact that the supply chain is a system of bi-directional flows. So goods flow forward from the textile producer to the customer and information about consumer demand, orders, and capacity commitments flows backward to apparel and textile manufacturers. In control systems terminology this is a system with both information feedforward and feedback, the advantages of which have been ably 
demonstrated by Wikner et al (13) and Mason-Jones and Towill (14). The innovative feature of $\mathrm{QR}$ is that actions are taken to increase the velocity of flows in both directions. The QR campaign involves re-engineering the pipeline to move apparel forward faster; that is, to shrink cycle times at each stage of manufacture and the shipment times between stages. However the important actions were those taken to improve the responsiveness of the system through improved, faster communication of consumer preferences to all members of the chain.

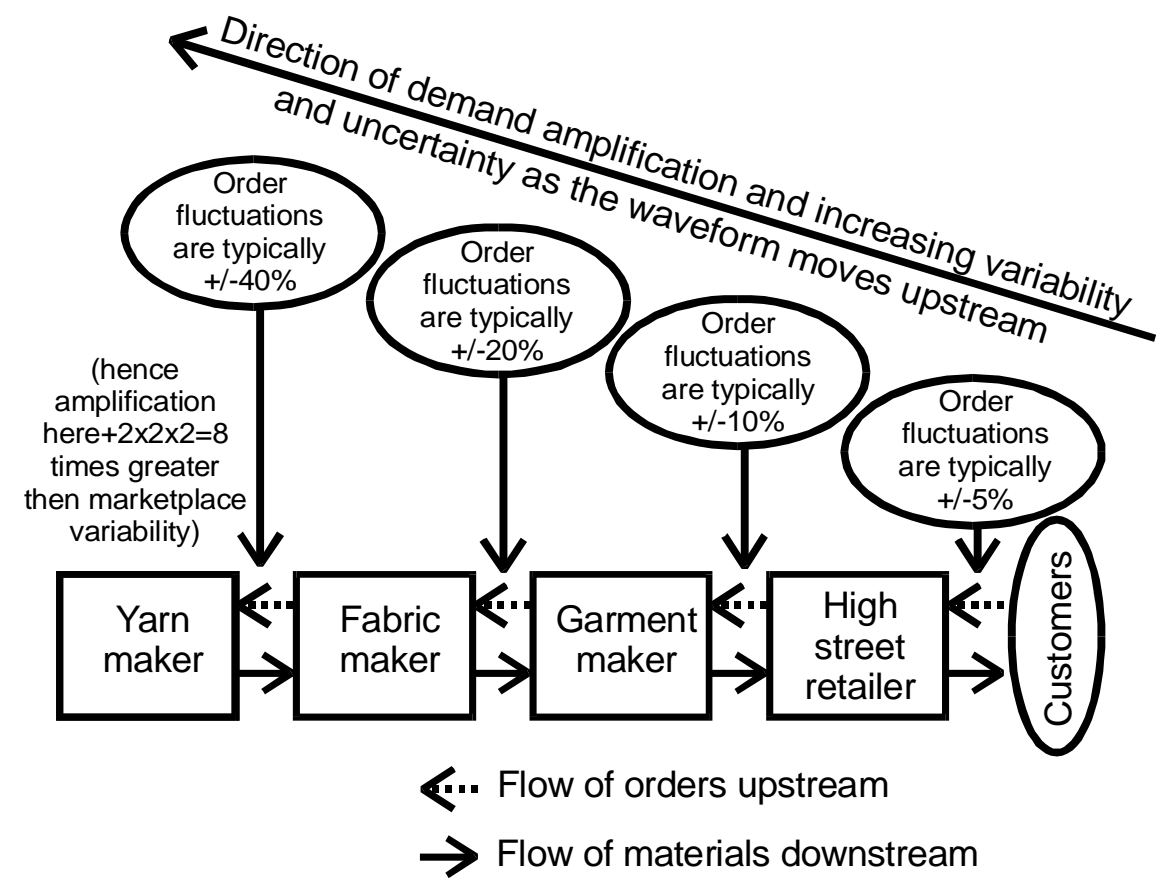

\section{Fig. 1. Sequential Information Flow Causing Bullwhip In A "Traditional" Clothing Supply Chain}

(Source: McCullen and Towill (2), based on the description by Stalk and Hout (15))

Unlike the "traditional", bullwhip generating, clothing supply chain described by Stalk and Hout (15), and shown schematically in Fig. 1, Quick Response is built upon a partnership involving each link in the chain from the producer of textiles right through to the retailer who sells the garment to the customer. The desired partnerships in QR extend beyond the paired relationships between supplier and buyer that are found in JIT systems; each link in the chain shares information about sales, 
orders, and inventories with the others. Retailers communicate information about sales, not only to the apparel manufacturer, but also back to the textile producer. Mutual co-operation among all partners is required if the system is to succeed in its goal of increasing sales with less inventory in the total system. A successful partnership means higher inventory turns and improved return on investment for each link in the chain.

\section{A trend to off-shore sourcing}

As we have previously noted, offshore sourcing and manufacturing has been an increasing trend across much of Western industry for several decades. The motivation for this tendency to offshore sourcing has been primarily cost. However, it could be argued that the concept of cost that has been employed in those decisions is narrow in the extreme because the cost criteria employed is essentially the unit cost of manufacture or purchase. Costs such as those associated with today's wider view of the supply chain are often ignored. Thus rarely is a realistic charge placed upon the additional inventory that inevitably will be created as pipelines lengthen, neither is a cost placed upon the risk that this might generate in terms of obsolescence, equally the impact on the firm's agility is not factored into the equation.

Whole sectors of industry - particularly in electronics and clothing - have migrated to the Far East as the search for lower labour cost intensifies. Strangely, even industries where labour costs represent only a small part of total value-added such as semiconductor fabrication have been seduced by this general trend.

A study by Lowson (16) of fifty European Union retailers found that $70 \%$ of their total purchases came from outside the EU at purchase prices up to 35\% lower than could be obtained locally. Companies such as Marks \& Spencer who as recently as 1990 sourced almost 100\% of their garments in the British Isles (UK and Republic of Ireland) had reduced this by half by 2000. A shirt sourced in Indonesia could be purchased by Marks \& Spencer buyers for $£ 2.69$ compared to $£ 6.01$ in Northern Ireland (17).

Lowson also highlighted the fact that the retailers in his study were typically working on order to delivery lead-times of between 48 and 60 weeks when ordering from 
Asian sources. This clearly inhibits their agility and has the potential to place themselves at some risk if demand for those products does not come up to expectations.

The same survey also examined the extent to which retailers' flexibility was affected by their choice of sourcing location. The findings are summarised in Table 2 below.

\section{Take in table 2}

To highlight the differences in flexibility and responsiveness by source location we have applied a numerical weight to each column as follows:-

$\begin{array}{ll}\text { None } & \text { x } 0 \\ \text { Some } & \text { x } 1 \\ \text { Substantial } & \text { x } 3\end{array}$

The three resulting scores are then summed and divided by 300\% (the maximum possible score) to produce a metric highlighting volume and mix responsiveness before and after the sales season commences. It seeks to provide a single aggregate "score" which sheds insight into sourcing decisions, especially when coupled with vendor lead times.

Table 3 shows the resulting scores along with the average lead-time that the respondents associated with each sourcing location.

\section{Take in table 3}

These results suggest that the loss of flexibility that results from sourcing offshore can be significant. The paradox is that these data are derived from retailers themselves but dramatic though they may be, they seem not to influence the manufacturing costbased sourcing decisions. Whilst these findings result from a survey of retailers they are not dissimilar to the experience of companies in industries such as electronics or high technology generally. 
What is called for is a wider definition of costs which is based upon total supply chain costs. The limited definition of cost that is still the main driver in sourcing decisions (i.e. unit manufacturing or purchase cost) is clearly inadequate and will not reflect the true total costs of ownership. True supply chain costs need to incorporate such elements as:-

- Inventory carrying costs

- cost of mark-downs

- cost of loss sales

- transaction costs (including letters of credit, customs clearance)

- transportation (including emergency airfreight)

- warehousing

- duties

There will be many occasions where, even taking all the above costs into account, it will still make sense to source in low-cost, offshore locations. For example, standard products with limited variation in demand. However for other products where demand is much more volatile and harder to predict, local sourcing may be preferable.

The Concept of Separating Baseline and Surge DemandsA further option exists for a hybrid strategy where low-cost sourcing is adopted for the 'base' level demand (i.e. a minimum level of potential demand based upon past experience) with more responsive sourcing to cope with demand above that level. See Figure 2 below:- 
Figure 2 : Separating Base and Surge Demand

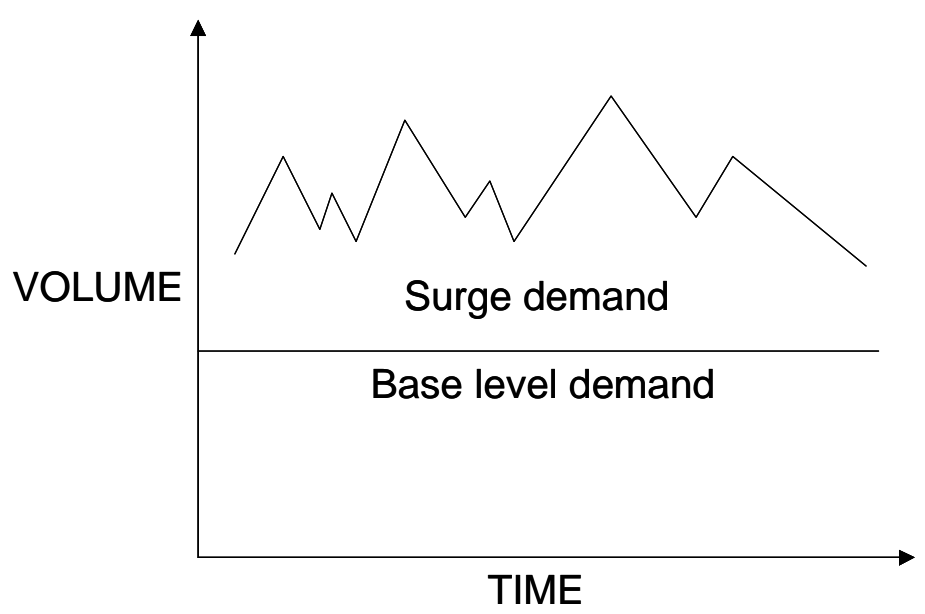

Splitting sourcing in this way enables demand forecasts to be based upon more recent sales information and thus forecast error should reduce. Such strategies can be enhanced by ordering components or material in advance of demand from low-cost sources and the assembling or manufacturing the final product locally to enable greater responsiveness. This is the strategy adopted by Zara the successful Spanish fashion retailer. Other retailers in that sector such as the UK chain Next are bringing more of their sourcing closer to their major markets in the UK and Ireland. Next now source a significant number of products from Eastern Europe and Turkey rather than the Far East (18).

Lowson (19) contrasted three European clothing retailers who used different sourcing strategies; low cost, responsive and hybrid and found some fascinating differences in their financial performance. Whilst the low-cost sourcing strategy produced the highest gross margin, it had the lowest return on investment. Conversely, the company with the responsive sourcing strategy had the lowest gross margin but the highest return on investment. Table 4 below which anticipates our dicussion of the "lean" and "agile paradigm highlights the results of the Lowson study:-

\section{Take in Table 4}




\section{The Decline of an Icon}

As an example of a business which has faced challenges in managing a global pipeline in a volatile market, we need look no further than Marks and Spencer (M\&S), a well-known UK retailer. As summarised by Christopher and Peck (20) the company had had a century of unbridled success, prior to their fall from grace. In the 1920s the business adopted the then revolutionary policy of buying direct from manufacturers, instead of through wholesalers. These unique supplier relationships gave the business an advantage that few of its rivals could match. By 1930 it was already recognisable as an established and effective practitioner of keiritsu with its supply base (21). Historically M\&S has designed most of its clothes in-house before putting the designs forward to favoured manufacturers with notoriously strict specifications regarding the finished product. These manufacturers provided dedicated facilities for $M \& S$ who required suppliers to refrain from bidding for work from other clients. The close partnerships arrangements also relieved $M \& S$ of the need to allocate resources of its own to technological research and development activities. The outcome of servicing such a demanding client was a culture of continuous improvement within the suppliers organisations and the loyalty of $M \& S$ through both good times and bad.

But this UK based supply strategy was inhibiting the development of the retail business in Asia and the Pacific. Also M\&S still officially encouraged its suppliers to source in the UK, enabling it to maintain its 'buy-British' marketing stance. But their suppliers were now struggling to remain price-competitive. Hence some had therefore opted to supply at least a proportion of M\&S's orders from overseas facilities or buy-in virtually finished goods produced in low-cost manufacturing centres such as China. So in order to comply with "home" sourcing requirements, the garments were then shipped to the UK for finishing. Some of the consignment would then need to be returned to the region of origin for sale! This round-trip lengthened the time delay before goods appeared in the shops, and in some instances distribution charges added as much as $£ 14$ to an item that cost only $£ 4$ to make.

In 1998/99 failure to match supply with demand resulted in too much winter stock costing M\&S $£ 150$ million, of which $£ 90$ million was lost from pre-Christmas sales, the remaining $£ 60$ million being the cost of clearing the excess stock. Some critics 
pointed to overpricing and poor service as the reasons behind these falling sales. Others claimed that customers were unhappy about a drop in quality of some products. Retail analysts were also talking of a decline in product quality, putting it down to an increase in overseas sourcing. In 1983 the company had sourced $90 \%$ of its clothing in the UK, by 1994 this had slipped to $75 \%$ and then further downwards to an estimated $65 \%$ in 1998 . To become price competitive, M\&S was then urging its largest suppliers to relocate production to low-wage economies. By January 2000 M\&S was indeed achieving its stated target by sourcing roughly $50 \%$ of its clothing and general merchandise outside the UK.

\section{When Price Deflation Impacts Demand}

Historically M\&S bought stock to cover over $100 \%$ of budgeted sales. Even now they still make a forward commitment to $90 \%$ of the season's merchandise. So the $10 \%$ uncommitted means there is far too little scope to respond when real demand is known.

Wheatcroft (22) further infers that the company's problems result largely from a failure by $M \& S$ to remedy core problems relating to supply chain design and operation. The symptoms are clearly visible via product-mix mismatch and nonavailability of key goods, especially in shoes and clothing. Disastrous performance in these two product ranges dragged down comparable sales for $M \& S$ as a whole by $8.4 \%$ for the five weeks to November 4, 2000. Typically, poor availability cost the knitwear division around £M6 in lost sales, and similar problems in the footwear division cost around £M5. Even more surprising and worrying to the company is the availability problem continuing to surround lingerie supply, which has a relatively stable and predictable demand pattern.

In contrast the year 2000 performance of their UK competitor Next was outstanding. Next share price rose $42 \mathrm{p}$ to $650 \mathrm{p}$ following pre-tax rise in profits of $18 \%$. Furthermore the Next CEO disputed claims that M\&S were suffering from the polarisation of the high street clothing market into branded goods at one end and discounted goods at the other. His view was that "Peoples' shopping habits are not changing. You just have to be good at what you do." The Next strategy is to be aspirational and affordable. Shopping on price deflation has come to an end. 
Shoppers are opting for higher-priced items as consumers become more interested in quality and design." (22). The Next sales growth continues to be maintained. Designing and managing the supply chain to deliver just what the customer wants yet again appears to be the key to business success.

As noted by Perry et al (23) in Australia there is now a clear trend for suppliers to the domestic market to focus on high value-added local-demand products that can compete with offshore imports. Also the evolution of the information economy has had a clear impact on the Australian textile, clothing and footwear industry, providing a potential means of control over emerging global supply chains. Communication with overseas supply chain partners was a challenge, calling for high levels of use of secure Extranets, EDI transaction platforms, CAD/CAM design and specification transfer, email, facsimiles and the telephone. Perry et al (23) concluded that there is a need for new organisational paradigms to cater for the increasingly complex supply chain. In leadership terms they found that the close-knit retail-to-upstream supplier partnerships that had been originally encouraged through government workshops and assistance programmes had been eroded somewhat through the retreat of the retailers back to their traditional power-based role of setting terms and standards for suppliers.

\section{Role of "Lean" and "Agile" Paradigms in Modern Supply Chains}

There has recently been some significant debate about the relative merits of the socalled "lean" and "agile" approaches to supply chain management. There has been a tendency to suggest that these approaches are mutually exclusive and represent conflicting paradigms. In reality the two approaches can complement each other, and in many cases there is a requirement for a "hybrid" lean/agile strategy to be adopted, (24). Hence it is our contention that the issue is not "Lean versus Agile" rather it is the judicious selection and integration of appropriate aspects of these paradigms appropriate to the particular supply chain strategy.

The idea of "lean manufacturing" was popularised by Womack, Jones and Roos, (25), together with the wider concepts of the "lean enterprise" (26). The focus of the lean approach has essentially been on the elimination of waste or muda. The upsurge of interest in lean manufacturing can be traced to the Toyota Production System (TPS) with its focus on the reduction and elimination of waste. However, the origins of lean 
manufacture are certainly visible in Spitfire aircraft production in the UK in World War II, and Keiretsu date back to the USA automotive industry in 1915.

\begin{tabular}{|c|c|}
\hline ACTIVITY LEVEL & CHARACTERISTICS OF AGILE ORGANISATION \\
\hline 1. MARKETING & $\begin{array}{l}\text { - Customer enriching, individualised combinations of } \\
\text { products and services }\end{array}$ \\
\hline 2. PRODUCTION & $\begin{array}{l}\text { - Ability to produce goods and services to customer orders in } \\
\text { arbitrary lot sizes }\end{array}$ \\
\hline 3. DESIGN & $\begin{array}{l}\text { - Holistic methodology integrating supplies, business } \\
\text { processes, customer and products use and disposal }\end{array}$ \\
\hline $\begin{array}{l}\text { 4. } \\
\text { ORGANISATION }\end{array}$ & $\begin{array}{l}\text { - Ability to synthesise new productive capabilities from } \\
\text { expertise of people and physical facilities regardless of } \\
\text { their internal or external location }\end{array}$ \\
\hline 5. MANAGEMENT & - Emphasis of leadership, support, motivation, and trust \\
\hline 6. PEOPLE & - Knowledgeable, skilled, and innovative total work force \\
\hline
\end{tabular}

Table 5

Relevance of Core Characteristics of Agile Manufacture Source: Authors based on Goldman, Nagel, and Preiss, (27)

Agility is a business-wide capability that embraces organisational structures, information systems, logistics processes and in particular, mindsets. A key characteristic of an agile organisation is flexibility. Initially it was thought that the route to manufacturing flexibility was though automation to enable rapid changeovers (i.e. reduced set-up times) and thus enable a greater responsiveness to changes in product mix or volume. Later this idea of manufacturing flexibility was extended into the wider business context and the concept of agility as a supply chain philosophy was born. Table 5 summarises this philosophy along six dimensions : marketing; production; design; organisation; management; and people. 


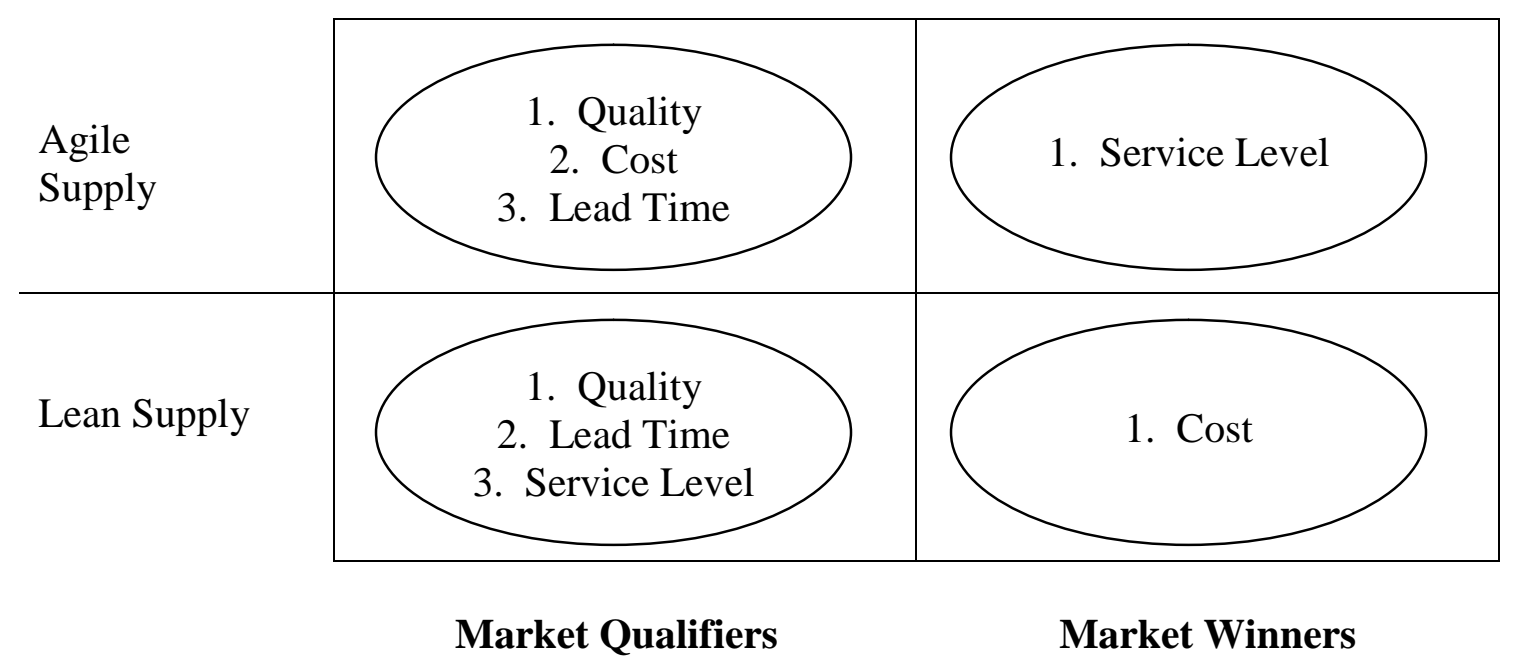

Fig. 3

Market Winners - Market Qualifiers Matrix for Agile Versus Lean Supply Source: Mason-Jones, Naylor, and Towill (7)

Ideally, organisations would wish to benefit from the advantages of being both lean and agile - they should not be viewed as mutually exclusive options. On the contrary, as we shall demonstrate, we may well find the lean and agile paradigms operating at different times but in the same place, or operating at the same time in different places within a supply chain. Furthermore, application of the Market Winners/Market Qualifiers Framework suggests that we may well need to operate with the leanest agile system or the most responsive lean system (28). This is because as shown in Fig. 3 availability is the market winner in agile supply, whereas cost is the market winner in lean supply but with cost and availability as market qualifiers respectively.

\section{A Taxonomy for Pipeline Selection}

It is clear that there can be a number of different pipelines which may be chosen to satisfy customer demand but that such pipelines must be selected to match the business strategy of the supply chain. The Marks and Spencer example demonstrates that pipelines must be carefully matched to market requirements. It is equally clear that in the current business environment that quite different pipelines may function alongside one another, each needing appropriate operating and management skills. It is also likely that products may well require different kinds of pipeline according to their position within the product life cycle. 
So pipelines are not fixed for all times. What is needed is continuous assessment of the product range and market characteristics so that changing scenarios may be identified. Against these product/market characteristics will be a number of alternative options for pipeline design, dependent upon supply lead-times.

A number of classification schemes have been proposed in the literature (see for example Childerhouse (29) to guide the choice of supply chain strategy. We are suggesting a simple three dimensional classification appropriate for global supply chains. The variables and their binary gradation are:

- Products (either standard or special)

- Demand (either stable or volatile)

- Lead Times (either short or long)

Figure 4 shows the theoretical combinations of product, demand and lead-times. In practice some of these combinations are either unlikely to be encountered or are nonviable situations. Where demand is stable it will generally be easier to forecast and hence inventory-based solutions may be appropriate, particularly where lead-times are long. However, by definition when demand is volatile, forecast-based management becomes untenable. Hence the need in those situations for agile supply chain strategies. Agility implies end-to-end time compression or postponement of final product configuration.

A further element to influence the choice of supply chain strategy is the specific 'market winner' criterion. Where cost is the primary market winner, then the emphasis must be upon efficiency which will imply lean strategies. However, the reality is that lean strategies will only be viable where demand is stable and the products are standard. Where availability is the market winner then the emphasis will inevitably veer towards agile strategies. 


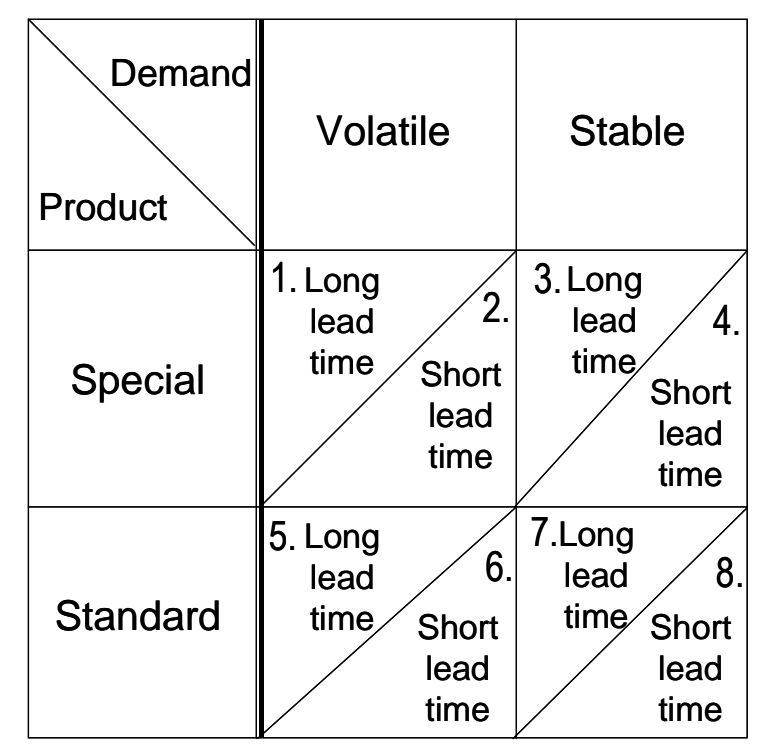

Figure 4 : A Taxonomy of Supply Chains

\section{An Adaptive Global Supply Chain}

From the foregoing it is now clear that in the $21^{\text {st }}$ century global supply chain strategies must correctly match the pipeline to the requirements of the marketplace. In particular there is a need to enable lean production to meet those situations where cost is the market winner. Additionally and concurrently we must enable agile production to counter those situations where availability is the market winner. Furthermore the adaptive supply chain must have the capability of switching pipelines as demanded by the requirements of the marketplace. The adaptive supply chain is therefore able to simultaneously compete on price (where required) and on availability (where required).

An example of such an adaptive supply chain already operating in the apparel industry is the Griffin Manufacturing Co (30). Their strategy combines a lean pipeline offshore (in Honduras) and an agile pipeline in the USA. Based on current trends there is an expectancy that in the long-term offshore production will be about $80 \%$ of the total volume. The remaining $20 \%$ is made in the USA.

The Griffin strategy was based on the following observations: 
- A significant fraction of orders requires "instant" response

- Forecasting accuracy is quite poor for a significant percentage of styles

- Excess inventory is very expensive

The resulting Griffin mix of process choice and order wining criteria are shown in Table 6.

\begin{tabular}{|l||l|l|}
\hline \multicolumn{1}{|c||}{ Business Requirement } & \multicolumn{1}{|c|}{ Process Choice } & Order Winning Criteria \\
\hline \hline New Product Introductions & Jobbing & $\begin{array}{l}\text { Fast Response, } \\
\text { Specification }\end{array}$ \\
\cline { 2 - 3 } Volume Orders & Large Batch & Price \\
\hline Fill-in Orders & Small Batch & Fast Response \\
\hline
\end{tabular}

\section{Table 6}

\section{Mix Process Choice and Order Winning Criteria Targeted by Griffin Business Strategy (Source; Stratton and Warburton (30))}

A typical measure of forecasting accuracy is that $70 \%$ of the styles have a prediction within $25 \%$ of sales. For those products with the most uncertain forecasts, it is reasonable to assign a lower percentage to offshore production and reserve capacity at an agile manufacturer. On the other hand, for basic styles that sell throughout the year, a much higher percentage of lean (offshore) production can be assigned. Griffin established a clear financial case that for their product range and typical forecast accuracies, the profit margins for a mixed offshore-onshore production strategy are competitive with the offshore only case. But with the mixed strategy, margins improve and sales increase because the agile manufacturer can take advantage of the early sales information to produce more of the styles the customers are actually demanding. Table 7 illustrates the Griffin viewpoint and summarises their considered consequences of using alternative pipelines to match and meet customer demand.

Take in table 7 
There are a number of challenges associated with the mixed (adaptive pipeline) strategy such as sharing the pain between retailer and manufacturer. In one sense what is required of the retailer using the adaptive supply chain is a much more challenging approach. Rather than ordering to forecast, the retailer has to analyse forecasts. It is their remit to decide on offshore (lean) production commitments, and USA (agile) capacity reservation. Hence retailers must share their sales data and work continuously with manufacturers to get the exact inventory they need. When sales increase, everyone will be satisfied. The retailer sells more products with fewer markdowns, resulting in less excess inventory. Also, the manufacturer can make minor adjustments (e.g. fill in sizes) to further tailor the inventory to the actual demand. Finally, there is less profit leakage via "cannibalisation" due to sales markdowns. Cannibalisation is the phenomenon whereby the customer buys two cheaper garments now, thus avoiding a full price purchase in the future.

The way that Griffin Manufacturing Co. have engineered and exploited the adaptive supply chain is shown in matrix format in Fig. 5. Along with the implied changes in operations a significant evolution in Griffin's management philosophy also occurred. Initially the USA factory used to view themselves as in competition with the Honduras factory, and resented every unit that went abroad as lost internal business. Eventually they came to realise that they could never compete on price alone, but did have an essential legitimate and complimentary cost-effective role in supplying the retailer. The days of large, stable production runs for the US plant have disappeared. But the reality is that the plant can survive by making small runs of complex styles, and producing them quickly. As shown in Fig. 5, the USA facility also "tops-up" high volume products as required to meet extreme demands. These two agile pipelines account for some $20 \%$ of the total volume. The Griffin strategy has thus protected US jobs by identifying the right agile home-based niches to complement lean Honduras manufacture. 


\begin{tabular}{|c|c|c|}
\hline Product & Volatile & Stable \\
\hline Special & $\begin{array}{l}\text { Innovative } \\
\text { Agile Pipeline } \\
\text { (USA) }\end{array}$ & Not Applicable \\
\hline Standard & $\begin{array}{l}\text { Top-up Agile } \\
\text { Pipeline } \\
\text { (USA) }\end{array}$ & $\begin{array}{l}\text { High Volume } \\
\text { Lean Pipeline } \\
\text { (Honduras) }\end{array}$ \\
\hline
\end{tabular}

Fig. 5.

Summary of the Griffin Manufacturing Company Pipeline Product Matrix for Lean and Agile Supply

(Source: Authors based on Stratton \& Warburton (30))

\section{Global Pipeline Taxonomies at Work}

How does the Griffin Manufacturing Co's. pragmatic solution to matching combinations of USA and Honduras apparel production align with the proposed pipeline taxonomy? The results may be summarised in Table 8.

\begin{tabular}{|l||l|l|l|}
\hline \multicolumn{1}{|c||}{$\begin{array}{c}\text { Griffin Manufacturing } \\
\text { Pragmatic Solution }\end{array}$} & \multicolumn{3}{c|}{ Pipeline Characteristics } \\
\cline { 2 - 4 } & Product & Demand & $\begin{array}{l}\text { Lead- } \\
\text { time }\end{array}$ \\
\hline Innovative Agile Pipeline & Special & Volatile & Short \\
\hline Top-Up Agile Pipeline & Std & Volatile & Short \\
\hline High Volume Lean Pipeline & Std & Stable & Long \\
\hline
\end{tabular}

Table 8

Alignment of Griffin Pipeline Solutions with Proposed Supply Chain Taxonomy 
How many significantly different pipelines do we really need? The biggest need is undoubtedly to move away from the "One Size Fits All" scenario. At the same time there is little point in selecting a taxonomy yielding multiple possible pipelines if the end result means that only a handful of solutions are eventually selected. This "filtering" may be on the basis of management preference for specific pipelines, or on the base of a cost-effectiveness model. We think a binary classification system has a number of advantages. Firstly, analysts have to make a firm judgement in such a situation - they cannot sit on the fence. Secondly, the use of binary codes tends to avoid regression to the mean "seeking to satisfy everyone, but pleasing no one". There is little point in using a taxonomy which does not lead to supply chain managers being offered real choices in a language they understand. Our proposed classification system based on Lead Times (Short/Long); Demand Predictability (Stable/Volatile) and Product Type (Standard/Special) meets this requirement.

\section{Conclusions}

Present day marketplaces are volatile and at the same time extremely price sensitive. Achieving success in this environment requires a good knowledge of pipeline requirements from marketing back to materials manufacturers. Within supply chains it is possible to identify some operations which are "lean" (without fat) and some operations which are "agile" (nimble). The aim is to select and marry together the particular combinations of lean/agile operations so as to match individual pipelines to market needs.

In the paper we have developed a taxonomy suitable for this purpose. It is based on demand (predictable/volatile), product (standard/special) and supply lead times (long/short). This is seen to generate three feasible pipeline designs, all of which are applicable within the global apparel supply chain framework. Generally the preferred solution will be that predictable demand for standard items will be met via a lean pipeline probably fed from overseas manufacturers. Volatile demand for special items will then be met via an agile pipeline probably fed from home manufacturers. A third pipeline design is for quick response to top-up standard products for which there is an unexpected demand for specific colours, sizes, volume etc. 


\section{References}

(1) Christopher, Martin, "Logistics and Supply Chain Management : Strategies for Reducing Costs and Improving Services" Pitman Publishing, London, 1992.

(2) McCullen, Peter and Denis R. Towill, "Practical Ways of Reducing Bullwhip: the case of the Glosuch global supply chain", International Journal of Operations Management, Vol 26, No. 10, 2000, pp 24-30.

(3) Shewchuck, John. P., “Agile Manufacturing : One Size Does Not Fit All”, Proc. Int. Conf. on Manufacturing Value Chains, Troon, 1998, pp 143-150.

(4) Fuller, Joseph B., James O'Connor and Richard Rawlinson, "Tailored Logistics : the Next Advantage", Harvard Business Review, May-June, 1993, pp 87-98.

(5) Fisher, Marshall L., Janice H. Hammond, Walter R Obermeyer, Ananath Raman, "Configuring a Supply Chain to Reduce the Cost of Demand Uncertainty", Production and Operations Management, Vol 6, No. 3, Fall, 1997, pp 211-225.

(6) Towill, Denis R. and Martin Christopher, "The Supply Chain Strategy Conundrum to be Lean or Agile or to be Lean and Agile", Proceedings of the International Logistics Symposium, Salzburg, 2001, pp 3-12.

(7) Mason-Jones, Rachel, James B. Naylor, and Denis R. Towill, "Lean, Agile or Leagile? Matching Your Supply Chain to the Marketplace", International Journal of Production Research, Vol 38(1`7), 2000, pp 4061-4070.

(8) Blackburn, Joseph D., "The Quick-Response Movement in the Apparel Industry: a Case Study in Time Compressing Supply Chains", in J.D. Blackburn (Ed) "Time Based Competition", Business One Irwin, Homewood, 1991, pp 246-269.

(9) Hill, Terry, Manufacturing Strategy : Text and Cases, Second Edition, MacMillan Press, London, 1993.

(10) Fisher, Marshall L., "What is the Right Supply Chain for your Product?", Harvard Business Review, March/April, 1997, pp105-116.

(11) Fisher, Marshall L., Janice H. Hammond, Walter R. Obermeyer, Ananath Raman, "Making Supply Meet Demand in an Uncertain World", Harvard Business Review, May-June, 1994, pp 83-93. 
(12) Lowson, Robert, Russell King and Alan Hunter (1999), Quick Response: Managing the Supply Chain to Meet Customer Demand, John Wiley and Sons Ltd., Chichester.

(13) Wikner, Joakim, Denis R. Towill, and Mohamed M. Naim, "Smoothing Supply Chain Dynamics", International Journal of Production Economics, Vol 22, No. 3, 1991, pp 231-248.

(14) Mason-Jones, Rachel and Denis R. Towill (1997) "Information enrichment: designing the supply chain for competitive advantage", International Journal of Supply Chain Management, Vol. 2, No. 4, pp 137-148.

(15) Stalk, Jnr. George H. and Hout, Thomas M., Competing Against Time, Free Press, New York, 1990.

(16) Lowson, Robert, "Analysing the Effectiveness of European Retail Sourcing Strategies”, European Management Journal, Vol. 19, No. 5, 2001, pp 543551.

(17) Christopher, Martin, and Helen Peck, "Moving Mountains at Marks and Spencer", Case Study, Council of Logistics Management, USA, 2001.

(18) Shamoon, Stella, “The Next Big Thing”, The Times, London, U.K., 30 March 2002.

(19) Lowson, Robert, "Analysing the Effectiveness of European Retail Sourcing Strategies”, European Management Journal, Vol. 19, No. 5, 2001, pp 543-551

(20) Christopher, Martin \& Helen Peck, "Moving Mountains at Marks \& Spencer", Case Study, Council of Logistics Management, USA, 2001.

(21) Drucker, Peter, "The Information that Executives Truly Need", Harvard Business Review, Jan-Feb, 1995, pp 55-63.

(22) Wheatcroft, Patience, Business Commentary, The Times, London, 13 September and 8 November 2000

(23) Perry, Marcia, Amrik S. Sohal and Richard Laney, "An Australian Quick Response Supply Chain Model" Proceedings ISL - Logistics and the Digital Economy Conference, Salzburg, 2001.

(24) Christopher, Martin and Denis R. Towill, "Marrying the Lean and Agile Paradigms", Proc. EUROMA Conference, Ghent, 2000, pp 114-121.

(25) Womack, James P., David T. Jones \& Daniel Roos, The Machine the Changed the World, Macmillan, USA, 1990.

(26) Womack, James P.\& David T. Jones, Lean Thinking, Simon \& Schuster, USA, 1996 
(27) Goldman, Steven N., Roger N. Nagel \& Kenneth Preiss, Agile Competitors and Virtual Corporations, 1995

(28) McCullen, Peter, and Denis R. Towill, "Manufacturing Agility and the Lean Supply Chain", Proc. MIM 2000 Conf, Aston, 2000, pp 424-431.

(29) Childerhouse, P., Enabling Seamless Market-Oriented Supply Chains, PhD Thesis, Cardiff University, 2001

(30) Warburton, Roger \& Roy Stratton, "Questioning the Relentness Shift to Offshore Manufacturing”, Supply Chain Management, Vol. 7, No. 2, 2002, pp 101-108. 


\begin{tabular}{|c|c|c|c|c|c|c|c|}
\hline \multirow[t]{2}{*}{$\begin{array}{l}\text { PIPELINE } \\
\text { MODEL }\end{array}$} & \multirow[t]{2}{*}{$\begin{array}{c}\text { FORECAST } \\
\text { SALES }\end{array}$} & \multirow[t]{2}{*}{$\begin{array}{l}\text { ACTUAL } \\
\text { DEMAND }\end{array}$} & \multicolumn{2}{|c|}{$\begin{array}{c}\text { MANUFACTURING MODE IN } \\
\text { "TRADITIONAL" SUPPLY } \\
\text { POLICY }\end{array}$} & \multicolumn{2}{|c|}{$\begin{array}{c}\text { MANUFACTURING MODE IN } \\
\text { "RESPONSIVE" SUPPLY } \\
\text { POLICY }\end{array}$} & \multirow{2}{*}{ CONSEQUENCES } \\
\hline & & & LEAN & AGILE & LEAN & AGILE & \\
\hline $\begin{array}{l}\text { "TRADITIONAL" } \\
\text { SUPPLY CHAIN } \\
\text { (Single Pipeline) }\end{array}$ & 1000 & 750 & 1000 & NIL & $* * *$ & $* * *$ & $\begin{array}{l}250 \text { excess } \\
\text { garments } \\
\text { declining } \\
\text { margins }\end{array}$ \\
\hline \multirow{2}{*}{$\begin{array}{l}\text { "ADAPTIVE" } \\
\text { SUPPLY CHAIN } \\
\text { (Multiple } \\
\text { Pipelines) }\end{array}$} & 1000 & 1250 & $* * *$ & $* * *$ & 800 & 450 & $\begin{array}{ll} & \text { happy } \\
& \text { customers } \\
\text { - } & \text { increased sales } \\
\end{array}$ \\
\hline & 1000 & 750 & $* * *$ & $* * *$ & 800 & NIL & $\begin{array}{ll}\text { - } & \text { few excess } \\
\text { garments } \\
\text { - } & \text { stable margins }\end{array}$ \\
\hline
\end{tabular}

Table 7

Marrying Lean and Agile Pipelines within the Adaptive Supply Chain

(Source: Authors based on Stratton and Warburton, (30)) 
Once order has been placed, what is the vendors' latitude for change?

Order volume change (\% respondents) Order mix change (\% respondents)

\begin{tabular}{|c|c|c|c|c|c|c|c|}
\hline & Sourcing regions & None & Some & Substantial & None & Some & Substantial \\
\hline Before the start of the sale season & $\begin{array}{l}\text { North America } \\
\text { European } \\
\text { Non-EU* } \\
\text { Central America } \\
\text { Asia } \\
\text { Africa } \\
\text { Other }\end{array}$ & $\begin{array}{l}41 \% \\
8 \% \\
29 \% \\
71 \% \\
67 \% \\
59 \% \\
33 \%\end{array}$ & $\begin{array}{l}37 \% \\
53 \% \\
44 \% \\
20 \% \\
21 \% \\
18 \% \\
41 \%\end{array}$ & $\begin{array}{c}22 \% \\
39 \% \\
27 \% \\
9 \% \\
12 \% \\
23 \% \\
26 \%\end{array}$ & $\begin{array}{l}58 \% \\
21 \% \\
37 \% \\
76 \% \\
71 \% \\
63 \% \\
31 \%\end{array}$ & $\begin{array}{l}28 \% \\
47 \% \\
39 \% \\
19 \% \\
18 \% \\
19 \% \\
37 \%\end{array}$ & $\begin{array}{c}14 \% \\
32 \% \\
24 \% \\
5 \% \\
11 \% \\
18 \% \\
34 \%\end{array}$ \\
\hline After the start of the sale season & $\begin{array}{l}\text { North America } \\
\text { European } \\
\text { Non-EU* } \\
\text { Central America } \\
\text { Asia } \\
\text { Africa } \\
\text { Other }\end{array}$ & $\begin{array}{l}57 \% \\
19 \% \\
34 \% \\
63 \% \\
71 \% \\
62 \% \\
32 \%\end{array}$ & $\begin{array}{l}22 \% \\
47 \% \\
39 \% \\
32 \% \\
20 \% \\
10 \% \\
43 \%\end{array}$ & $\begin{array}{c}21 \% \\
34 \% \\
17 \% \\
15 \% \\
8 \% \\
18 \% \\
25 \%\end{array}$ & $\begin{array}{l}62 \% \\
27 \% \\
62 \% \\
64 \% \\
87 \% \\
74 \% \\
39 \%\end{array}$ & $\begin{array}{l}18 \% \\
40 \% \\
34 \% \\
29 \% \\
11 \% \\
7 \% \\
36 \%\end{array}$ & $\begin{array}{c}20 \% \\
33 \% \\
4 \% \\
7 \% \\
2 \% \\
19 \% \\
23 \%\end{array}$ \\
\hline
\end{tabular}

Table 2 : Suppliers Latitude for Volume and Mix Change both Before and During Sales Season (by Vendor Geographic Region) 


\begin{tabular}{|l|c|c|c|c|c|}
\hline \multirow{2}{*}{ Sourcing Region } & \multirow{2}{*}{$\begin{array}{c}\text { Typical Lead Time } \\
\text { To Finalise }\end{array}$} & \multicolumn{4}{|c|}{ Composite Response Metric } \\
\cline { 3 - 6 } & Orders (Weeks) & Volume Change & Order Mix & \multicolumn{2}{c|}{ After Start of Season } \\
\cline { 3 - 6 } & $\mathbf{3 5}$ & .34 & .23 & .28 & .30 \\
\hline North America & $\mathbf{1 2}$ & .57 & .48 & .49 & .26 \\
\hline European & $\mathbf{2 1}$ & .42 & .37 & .25 & .46 \\
\hline Non-EU & $\mathbf{3 8}$ & .16 & .11 & .15 & .17 \\
\hline Central America & $\mathbf{5 5}$ & .19 & .17 & .21 & .06 \\
\hline Asia & $\mathbf{3 9}$ & .29 & .24 & .39 & .21 \\
\hline Africa & $\mathbf{3 4}$ & .40 & .46 & & .35 \\
\hline Other & & & & \\
\hline
\end{tabular}

Table 3 : Estimate of Vendor Responsiveness to Volume Change and Mix Change According to Geographic Region

(Source : Authors based on Survey results Undertaken by Lowson (16)) 


\begin{tabular}{|c|c|c|c|}
\hline Measure & $\begin{array}{l}\text { Retailer C- domestic, responsive and } \\
\text { flexible strategy. } \\
\text { European retailer with own small } \\
\text { manufacturing operation. A large European } \\
\text { and North American operation. Sources from } \\
\text { 'preferred' manufacturers in, Europe and } \\
\text { North America. Strategic objective of } \\
\text { attempting to use only domestic sources of } \\
\text { supply as far as possible. }\end{array}$ & $\begin{array}{l}\text { Retailer B - combined strategy - } \\
\text { using foreign and domestic } \\
\text { sources in the same season. } \\
\text { Independent EU-retailer. 'Own' or } \\
\text { 'private' label. Bulk of pre-season } \\
\text { goods, increasingly provided from } \\
\text { Asia but re-orders from 'dedicated' } \\
\text { EU supplier who only manufactures } \\
\text { for this retailer. }\end{array}$ & $\begin{array}{l}\text { Retailer A - offshore, low cost } \\
\text { strategy. } \\
\text { EU-based speciality clothing } \\
\text { store. European and North } \\
\text { American outlets. No } \\
\text { manufacturing capability. } \\
\text { Sources mostly offshore (Asia, } \\
\text { North and Central America). }\end{array}$ \\
\hline $\begin{array}{l}\text { GM/Sales Revenue } \\
\text { GMROI }^{\mathrm{a}} \\
\text { Inventory Turns }^{\mathrm{c}} \\
\text { Average Inventory }^{\mathrm{d}} \\
\text { Sales Revenue }^{\mathrm{e}} \\
\text { Service Level }^{\mathrm{f}} \\
{\text { Lost Sales } \%^{\mathrm{g}}}^{\text {Sell Through } \%^{\mathrm{h}}} \\
\text { Sold off } \%^{\mathrm{I}}\end{array}$ & $\begin{array}{c}\mathbf{0 . 4 3} \\
\mathbf{5 . 7 5} \\
7.20 \\
1.10 \\
1.00 \\
96.00 \\
6.40 \\
91.40 \\
0.87\end{array}$ & \begin{tabular}{c|}
0.47 \\
4.34 \\
5.30 \\
1.80 \\
0.64 \\
81.00 \\
13.70 \\
80.78 \\
7.80
\end{tabular} & \begin{tabular}{|c|}
$\mathbf{0 . 6 1}$ \\
2.20 \\
1.70 \\
3.83 \\
0.53 \\
71.00 \\
19.00 \\
71.80 \\
17.00
\end{tabular} \\
\hline \multicolumn{4}{|c|}{ 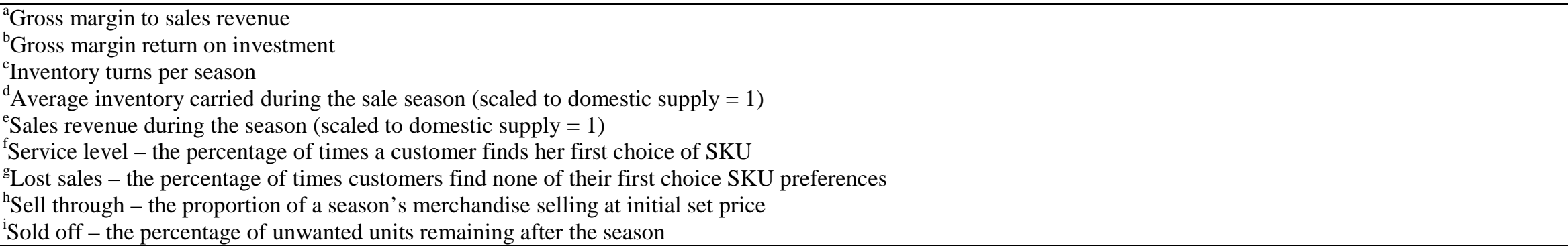 } \\
\hline
\end{tabular}

Table 4 : Sourcing Performance in Single Season

Replace with the following? 


\begin{tabular}{|c|c|c|c|c|c|}
\hline \multirow[b]{2}{*}{ Sourcing Strategy } & \multicolumn{5}{|c|}{ Resultant Sourcing Performance Metric } \\
\hline & $\begin{array}{c}\text { Gross Margin } \\
\text { (to sales revenue) }\end{array}$ & $\begin{array}{l}\text { Gross Margin } \\
\quad \text { (return on } \\
\text { investment) }\end{array}$ & $\begin{array}{l}\text { Service Level } \\
\text { (chance of } \\
\text { customer funds } \\
\text { first choice SKU) }\end{array}$ & $\begin{array}{l}\text { Sell Through } \\
\text { (proportion of } \\
\text { merchandise sold } \\
\text { at full price) }\end{array}$ & $\begin{array}{c}\text { Inventory Turns } \\
\text { (per season) }\end{array}$ \\
\hline $\begin{array}{l}\text { Retailer A Lean Pipeline } \\
\text { Offshore, low cost strategy }\end{array}$ & 0.61 & 2.20 & $71 \%$ & $71.80 \%$ & 1.70 \\
\hline $\begin{array}{l}\text { Retailer B } \sim \text { Hybrid Lean/Agile Pipelines } \\
\text { Combined strategy using foreign and } \\
\text { domestic sources in the same season }\end{array}$ & 0.47 & 4.34 & $81 \%$ & $80.78 \%$ & 5.30 \\
\hline $\begin{array}{l}\text { Retailer C } \sim \text { Agile Pipeline } \\
\text { Domestic, responsive and flexible strategy }\end{array}$ & 0.43 & 5.75 & $96 \%$ & $91.4 \%$ & 7.20 \\
\hline
\end{tabular}

\section{Table 4}

How the Responsive Pipeline Delivers Enhanced Bottom-Line Performance

(Authors: Based on Lowson, 2001) 
Denis R. Towill is a University of Wales Research Professor and is presently Co-Director of the Logistics Systems Dynamics Group at Cardiff University. In 2000 he was awarded the Lord Hirst Premium by the Council of the Institution of Electrical Engineers for the paper

"Management Theory - is it of any practical use?" Professor Towill has worked with many industries, including automotive, aerospace, mechanical, construction, electronic, steel supplies, and healthcare supply chains. He holds the degree of D.Sc from the University of Birmingham. In 1988 he was elected a Fellow of the Royal Academy of Engineering in recognition of his contributions on the theory and application of systems engineering to a range of European industries. He can be reached at Cardiff University, Cardiff Business School, Aberconway Building, Colum Drive Cardiff, CF10 3EU, Wales, UK, Phone : 44 (0)29 20 876083, Fax : 44 (0)29 20874301.

Martin G Christopher is Professor of Marketing and Logistics at Cranfield School of Management, Cranfield University, UK. He is also Chairman of the Cranfield Centre for Logistics and Transportation, Europe's leading centre for teaching and research in logistics and supply chain management. Dr Christopher is an Emeritus Fellow of the Institute of Logistics and Transport in the UK who in 1988 awarded him the Sir Robert Lawrence Gold Medal for his contribution to logistics education. In 1997 he was jointly awarded the Council of Logistics Management's Founder's Award. He can be reached at Cranfield School of Management, Cranfield University, Cranfield, Bedford, England, MK43 0AL. Phone : 441234751122 , Fax : 441234752691. 